\title{
Evaluation of Microbiological Stability of Frozen Fermented Dairy Drink Prebiotic Flavored Caja-Umbu
}

\author{
Elisângela De Andrade Castro (I), Elisabeth Mariano Batista (I), \\ Poliana Brito De Sousa (II,I), Antonio Belfort Dantas Cavalcante (I), \\ Marlene Nunes Damaceno (I) \\ (I) IFCE - Instituto Federal do Ceará - Campus Limoeiro do Norte (Rua Estevão Remigio, N \\ 1145, Centro, Limoeiro do Norte - CE.), (II) IFPI - Campus Urucui - Instituto Federal do Piauí \\ - Campus Uruçuí (Rodovia PI 247 km 7 s/n, zona rural, Portal dos Cerrados, Uruçuí - PI.)
}

\section{Resumo}

The consumers, more and more, have looked for foods that contribute directly to their health. Foods that have properties to reduce the risk of chronic diseases and improve health are known as functional foods. Among the functional prebiotic foods, fructo-oligosaccharides (FOS), not conventional sugars, not metabolized by the human body, noncaloric, selectively promote the growth of probiotics as Acidophillus and Bifidus, plus a number of benefits to human health, from reducing serum cholesterol to aid in preventing some types of cancer besides being used as a sucrose substitute. Some studies have proved able to process ice cream the frozen type employing different ferments and prebiotic ingredients. This study aimed to develop a frozen fermented dairy drink prebiotic, added pulp caja-umbu (Spondias spp) and evaluate the microbiological stability of the product ready for consumption. Three formulations were prepared ranging the concentrations of FOS and sucrose: (F1=0\% e $14.58 \%$; F2 $=3 \%$ e $11.58 \%$; F3=6\% e $8.58 \%$ ), respectively. The other ingredients were standardized: fermented dairy drink (51\%), prepared pulp (30.02\%), neutral alloy (1\%), emulsifier/stabilizer (1\%) and powdered whole milk (2.4\%). Conducted analyzes of coliform count at $45^{\circ} \mathrm{C}$, Staphylococcus aureus and Salmonella sp 25g, by rapid microbiological testing system in Petrifilm ${ }^{\mathrm{TM}}$ plates, during the times 1, 7, 14, 21, 28 and 35 days of storage at $-18^{\circ} \mathrm{C}$, according to the Technical Regulation on 
Microbiological Standards for Foods. The prepared formulations met the microbiological standards set in legislation with values of $<1 \times 10^{1} \mathrm{CFU} / \mathrm{g}$ for thermotolerant coliforms and Staphylococcus aureus and absence Salmonella. The results show good manufacturing practices, quality of raw material used and appropriate storage conditions.

Palavras-Chave: frozen, fructo-oligosaccharides (FOS), caja-umbu Agência de Fomento: PRÓ-INFRA/IFCE (EDITAL No 13/2013-PRPI); Ceará Foundation for the Support of Scientific and Technological Development (FUNCAP) 